\title{
Description of the technique of upper gastrointestinal series radiological examination for the evaluation of the esophagus, stomach and duodenum of Wistar female rats ${ }^{1}$
}

\author{
Descrição de técnica radiológica contrastada de esôfago, estômago e duodeno em ratas Wistar
}

\author{
João Vicente Machado Grossi', Roberto Fernandes NicolaII, André Vicente Bigolin", Juliano Hermes Maeso Montes", Juliano \\ Nunes Chibiaque de Lima", Raul Kraemer ${ }^{\text {III }}$, LeandroTotti Cavazzola ${ }^{\text {IV }}$ \\ ${ }^{\mathrm{I}} \mathrm{MD}$, Resident. Department of Surgery, Faculty of Medicine, ULBRA, Brazil.

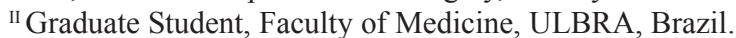 \\ ${ }^{\text {III }}$ MD, Full Professor of Radiology, Faculty of Medicine, Department of Medicine, ULBRA, Brazil. \\ IV PhD, Full Professor of Morphology and Surgery, Faculty of Medicine, ULBRA. Full Professor of Human Anatomy, Federal University of Health \\ Sciences, Porto Alegre - RS, Brazil.
}

\begin{abstract}
Purpose: To evaluate the anatomy of female Wistar rats and the workability of contrast radiography as a technique to investigate the gastrointestinal series. Methods: Eight adult female Wistar rats were undergone to the contrast radiography as anteroposterior incidence and as posterior incidence in profile. The radiological examination was conducted at a $45^{\circ}$ angle to the radiological table. Film-focus distance (FFD) was $100 \mathrm{~cm}$, film-object distance (FOD) was $0 \mathrm{~cm}$, and object-focus distance (OFD) was $100 \mathrm{~cm}$. An orogastric probe was used to inject barium contrast at 5-min intervals, for a total of four applications. After the radiological examination, animals were necropsy for confirmation of the radiological findings, and the radiographs were the absence of the normal anatomy variations inspected and described by an experienced radiologist. Results: All the radiographs produced achieved satisfactory results in terms of position, exposure, location and quality. The upper esophageal sphincter (UES) was identified in the esophagus at the nerve C2, the lower esophageal sphincter (LES) was identified between spinal cord segments L1 and L2, the thoracic-abdominal junction was observed at T10, the esophageal-gastric junction (EGJ) at T13-L1, with the abdominal portion in the epigastric region. The stomach was observed mostly in the epigastric region, left hypochondrium, left and mesogastric flank. The duodenum findings presented higher variation, with most findings identified in the epigastric region, right hypochondrium, right flank and mesogastric ileal fossa at T13-L5. Conclusion: Contrast radiology is useful and may be employed to assess the anatomy of the animal being studied. The experimental model described afforded to fully identify all organs investigated, as well as other occasional relevant findings. No anatomical anomalies in the subsequent necropsy, confirming the radiographic findings.
\end{abstract}

Key words: X-Rays. Esophagus. Stomach. Duodenum. Rats.

\section{RESUMO}

Objetivo: Avaliar a anatomia normal de ratas Wistar e a viabilidade do exame contrastado nesta população. Métodos: Foram submetidas ao exame oito ratas Wistar adultas, em incidência Ântero-Posterior e Perfil. A técnica consiste no posicionamento à $45^{\circ}$ de inclinação em relação à mesa radiológica e colocado à Distância Foco Filme (DFF) de $100 \mathrm{~cm}$, Distância Objeto Filme (DOF) de $0 \mathrm{~cm}$, Distância Foco Objeto (DFO) de $100 \mathrm{~cm}$. O contraste baritado foi injetado via sonda nasoesofágica, em intervalos de 5 minutos para cada fase, em um total de quatro fases. Após a realização do exame foi realizada necropsia dos animais para confirmação dos achados radiológicos e da ausência de variações da anatomia normal As radiografias foram analisadas e descritas por radiologista experiente no exame. Resultados: Todos os exames foram satisfatórios no que se refere ao posicionamento, exposição, localização e qualidade do exame. Foi identificado o esôfago com o Esfíncter Esofágico Superior (EES) ao nível de segunda vértebra cervical (C2) e Esfíncter Esofágico Inferior (EEI) entre as vértebras lombares (L1-2), transição toracoabdominal na vértebra Torácica (T10), Junção Esôfago Gástrica em T13-L1, com a porção abdominal em região epigástrica. O estômago, predominantemente, localizou-se em região epigástrica, hipocôndrio esquerdo, flanco esquerdo e mesogástrico. O duodeno teve a maior variação, com predomínio dos achados na região epigástrica, hipocôndrio direito, flanco direito, fossa ilíaca direita e mesogástrica e ao nível de T13-L5. Conclusão: O exame contrastado pôde avaliar a anatomia normal do animal em estudo e foi identificada de forma integral em todos os órgãos avaliados com o método descrito, achados confirmados em todos os animais em necropsia subseqüente.

Descritores: Raios x. Esôfago. Estômago. Duodeno. Ratos.

${ }^{1}$ Research performed at Experimental Laboratory, Institute of Basic Health Sciences, Brazilian Luteran University (ULBRA), Brazil. 


\section{Introduction}

The contrast radiological examination of the esophagus, stomach and duodenum is greatly useful in routine clinical and surgical evaluations ${ }^{1}$.

The veterinary radiology has utilized radiological examinations as a diagnosis tool, and the literature shows examples of investigations conducted with small animals ${ }^{2,3}$.

The contrast radiology affords to visualize several esophageal changes. The technique describes lesions like thickness or filling defects (suggestive of cancer), peptic stenoses, ulcers, as well as hiatal hernias. One of the limitations in study is the identification of small masses and the initial stages of the disease ${ }^{4,6}$.

The conduction of contrast radiology in accordance with an appropriate technique is of major importance in the effective diagnosis of gastrointestinal conditions. The exposure factors for an adequate basic radiological examination include peak kilovoltage $(\mathrm{kVp})$ and milliamperage per second (mAs). The factors that evaluate the quality of the radiological image include: (I) density, which determines the degree the film is blackened (mAs); (II) contrast, which differentiates the density of the adjacent areas $(\mathrm{kVp})$; (III) detail, which implies the clarity of structures (and that may vary due to movement, whether voluntary or not); and (IV) distortion, which is the wrong representation of size or format of the object as defined by the film-focus distance (FFD) and beam divergence ${ }^{13,15}$.

Considering the lack of a description of a radiology technique and of anatomic findings, location reference or position of the esophagus, stomach and duodenum in rats, we adopted an anatomical animal model based on subdivisions into quadrants and relative height against the vertebral column. This normality model is fundamental for the comparison of post-surgical studies of the esophagus, stomach and duodenum of rodents, in future research ${ }^{11,13-15}$.

To assess the radiological method utilized in terms of the quality and identification of the esophagus, stomach a duodenum of female Wistar rats.

\section{Methods}

This paper, is an original, retrospective study of randomized experimental design. The study sample consisted of 8 adult female Wistar rats with 16-week-old and weighing between 170 and $240 \mathrm{~g}$. Randomized performed by arbitrarily assigning the rats a set of initials. All animals were maintained in individual cages with two animals in each cage, in a controlled temperature environment $\left(22-24^{\circ} \mathrm{C}\right)$. Water and feed were ad libitum.

Inclusion criteria were:

1) Female Wistar rat, age between 15 and 16 weeks;

2) Not siblings;

3) No previous treatment;

Exclusion criteria were:

1) Visible anatomical distortion, observed before the radiological examination;

2) Anatomical distortion observed as of necropsy.
Images were examined by an experienced radiologist, who was blinded to the identification of the specimen analyzed. In virtue of the non-availability of male rats it was used only female rats. The radiological findings thus recorded were latterly compared to the necropsy findings. The radiological equipment used had a fixed base, with the X-ray tube being always positioned parallel to the film and at a $45^{\circ}$ inclination to the radiological table. The radiological beam was emitted at $36 \mathrm{~kW}$ and $32 \mathrm{~mA}$. Impression was conducted in mamographic ECRAM film. Photographic images were captured using a digital camera.

The present study was approved by the Ethics Committee in Research, Lutheran University Luteran of Brazil (ULBRA). The procedures and management of animals were supervised by the veterinary in charge of the institutions bioterium.

The procedures were conducted according to the stages described below:

I. Fasting. A 12-h fasting period was observed, though with water offered continuously.

II. Anesthesia. Intramuscular injections of Atropin SC 10 (0.044 $\mathrm{mg} / \mathrm{kg}$ body weight) were applied. After, the animals underwent general anesthesia using a mixture of xylazine $2 \%$ and ketamine $50 \mathrm{mg}$ as intramuscular injections $(0.1 \mathrm{ml} / 100 \mathrm{~g}$ body weight).

III. Positioning and probing. Animals were placed in dorsal recumbency at a $45^{\circ}$ angle to the horizontal plane of the radiological table. (Figure 1) The film compartment was supported by the upper limbs at a film-focus distance (FFD) of $100 \mathrm{~cm}$, film-object distance (FOD) of $0 \mathrm{~cm}$, and object-focus distance (OFD) of $100 \mathrm{~cm}$. Orogastric probing was conducted using a nr. 4 probe, placed $7 \mathrm{~cm}$ away from the oral cavity. The first radiograph was taken at anteroposterior incidence (AP) for confirmation of the position at the distal esophagus end.

IV. Injection of the contrast. The contrast (barium sulfate $100 \%$ ) was administered 4 times at 5 -min intervals. Contrast volumes were $0.3,0.6,0.3$, and $0.3 \mathrm{ml}$, totaling $1.2 \mathrm{ml}$. If the organ to be visualized was not filled, an extra volume of $0.4 \mathrm{ml}$ was injected. After the first injection of contrast $(0.3 \mathrm{ml})$ the second radiograph was taken, which revealed the esophagus and the esophagogastric junction, as well as the gastric content. Subsequently, $0.6 \mathrm{ml}$ contrast was administered, reaching the gastroduodenal junction. The duodenum-jejunum junction was filled at the third phase, with the injection of the $0.3-\mathrm{ml}$ contrast volume. If satisfactory, after the third phase the rat was placed on right lateral decubitus for the conduction of the profile $\mathrm{X}$-ray $(\mathrm{P})$.

V. Necropsy. Immediately after the end of the procedure, the animals were administered a $10 \%$ potassium chloride intracardiac injection, while still anesthetized at plane three.

VI. Verification of the technique. The radiological examinations obtained were sent, after revelation, to be evaluated by a radiologist trained in RESD. The radiologist was instructed to assess the quality of the examination and to identify the anatomical structures typical of the species used. 


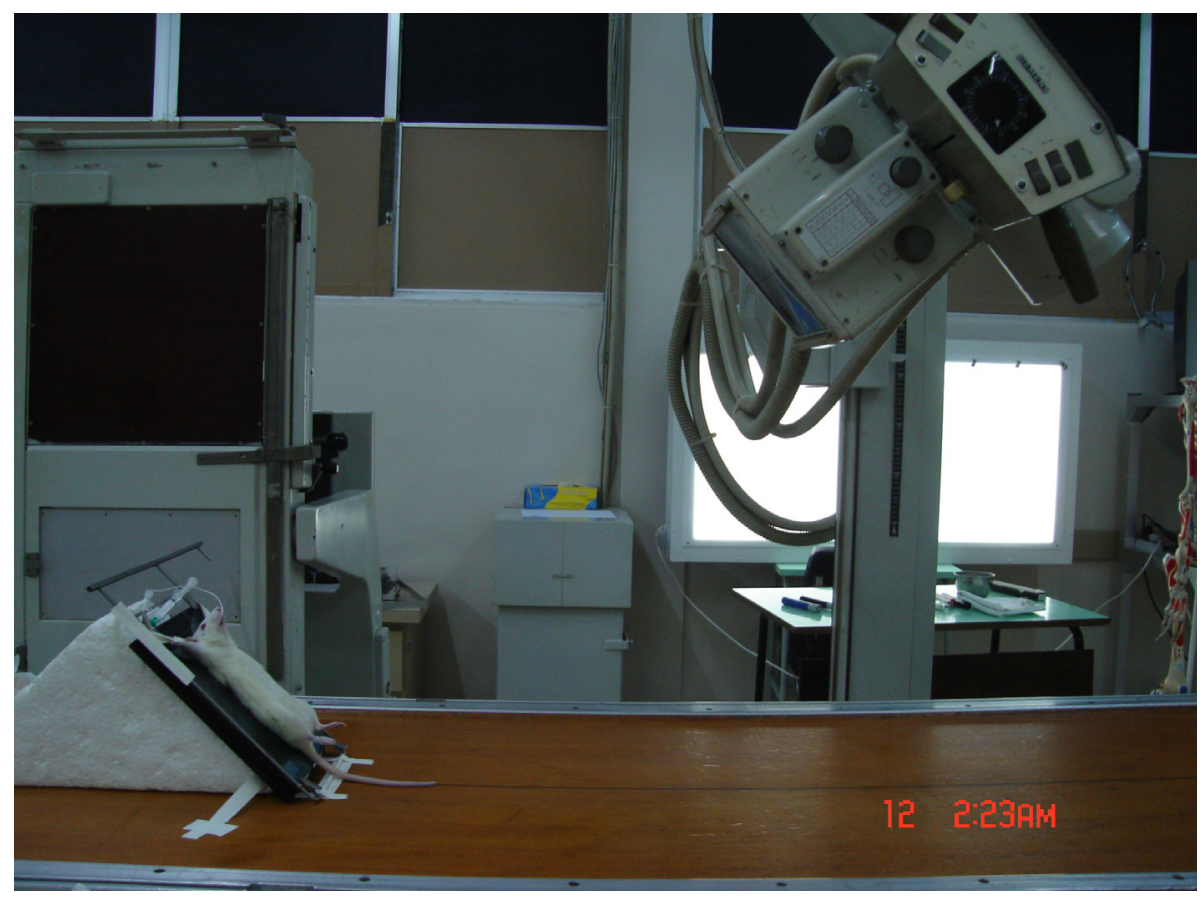

FIGURE 1 - Position of the specimens on the radiological table

\section{Results}

The analysis of the images revealed that in all the 8 animals studied, the regimens and positions were appropriate to afford the quality required for the assessment of the esophagus, stomach and duodenum (Figure 2).

As regards the species studied, the exam is considered normal when shows the usual structures forming the upper digestive tract. Apart from this, the assessment of the positions has to consider the specific details of the rat anatomy, as the presence of 13 thoracic vertebrae and of 6 lumbar vertebrae, for instance (Figure 3).

The esophagus was visualized showing its initial portion at the second cervical vertebra $(\mathrm{C} 2)$ the upper esophageal sphincter (UES) and located posterior to the trachea. The esophagus was identified in all the animals. The probe position was initially chosen to be between the thoracic vertebrae T10-13. Hemidiaphragms were positioned at T10 in all exams conducted. The esophageal-gastric junction was observed in the epigastric region and at T13-L1, in anteroposterior and posterior incidences. The lower esophageal sphincter (LES) was also observed at L1-2.

The thoracic-abdominal junction was observed at T11 in the esophageal hiatus, in all animals studied. The location of the lower esophageal sphincter (LES) and the hemidiaphragms with L1 and T10, respectively (Figure 4).

As regards the stomach, the gastric cardia was located in the epigastric region at T13 and L1, angular incisure at L1-2, fundus of stomach in the epigastric region, and left hypochondrium at T13-L1. The gastric body was also observed in the mesogastric region and left flank at L1-3, the antrum in the epigastric region at T13-L2, the pylorus in the epigastric region at T13-L1.

The duodenum was filled with contrast to the fourth duodenal portion, shown in the epigastric region, right hypochondrium, right flank, right iliac fossa, and mesogastric region, at T13-L5 (Figure 5).

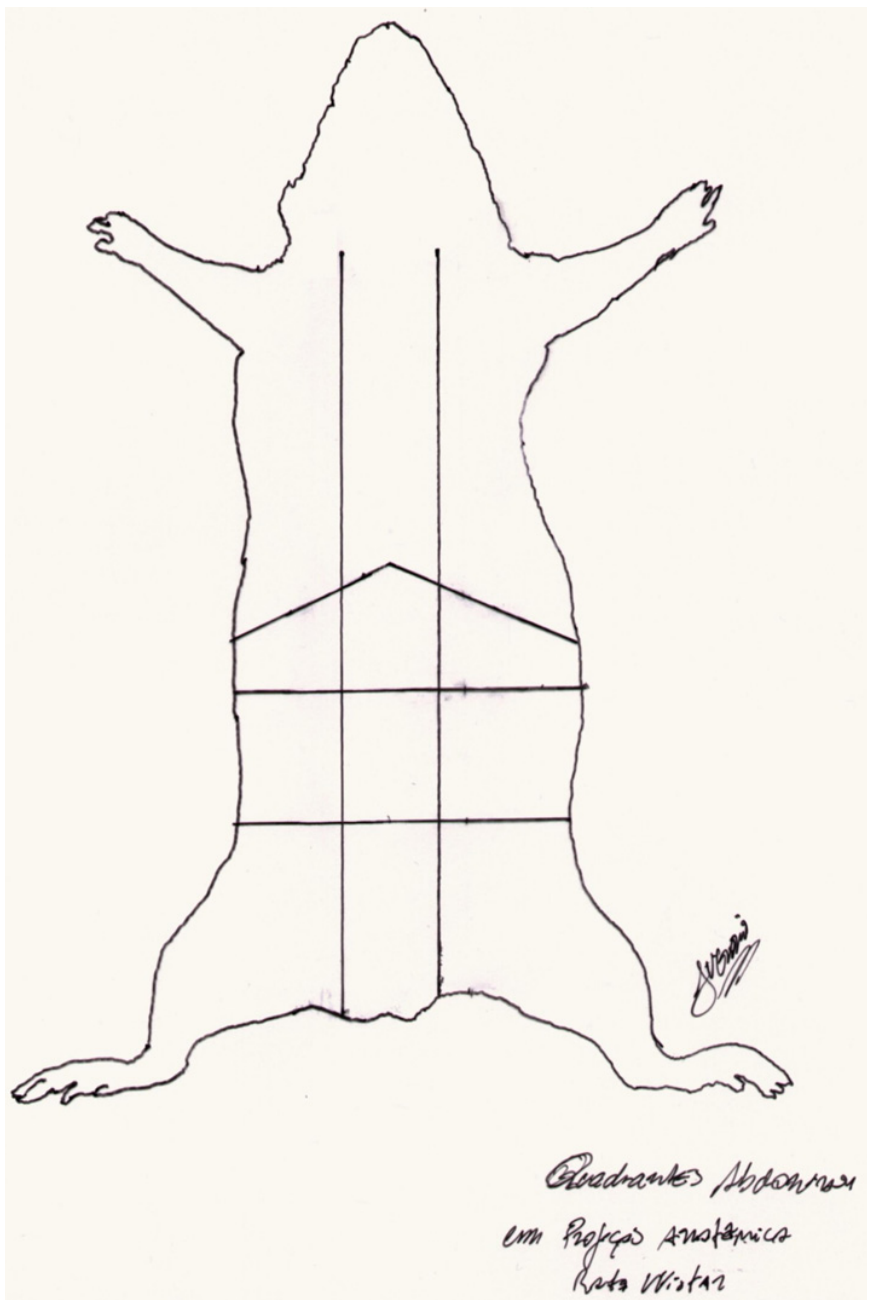

FIGURE 2 - Nine abdominal quadrants. Longitudinal divisions are defined by the hemiclavicular lines. Transversal divisions are defined by the lower L1 border, transpyloric plane, and line on the iliac crests on the lower L5 edge 


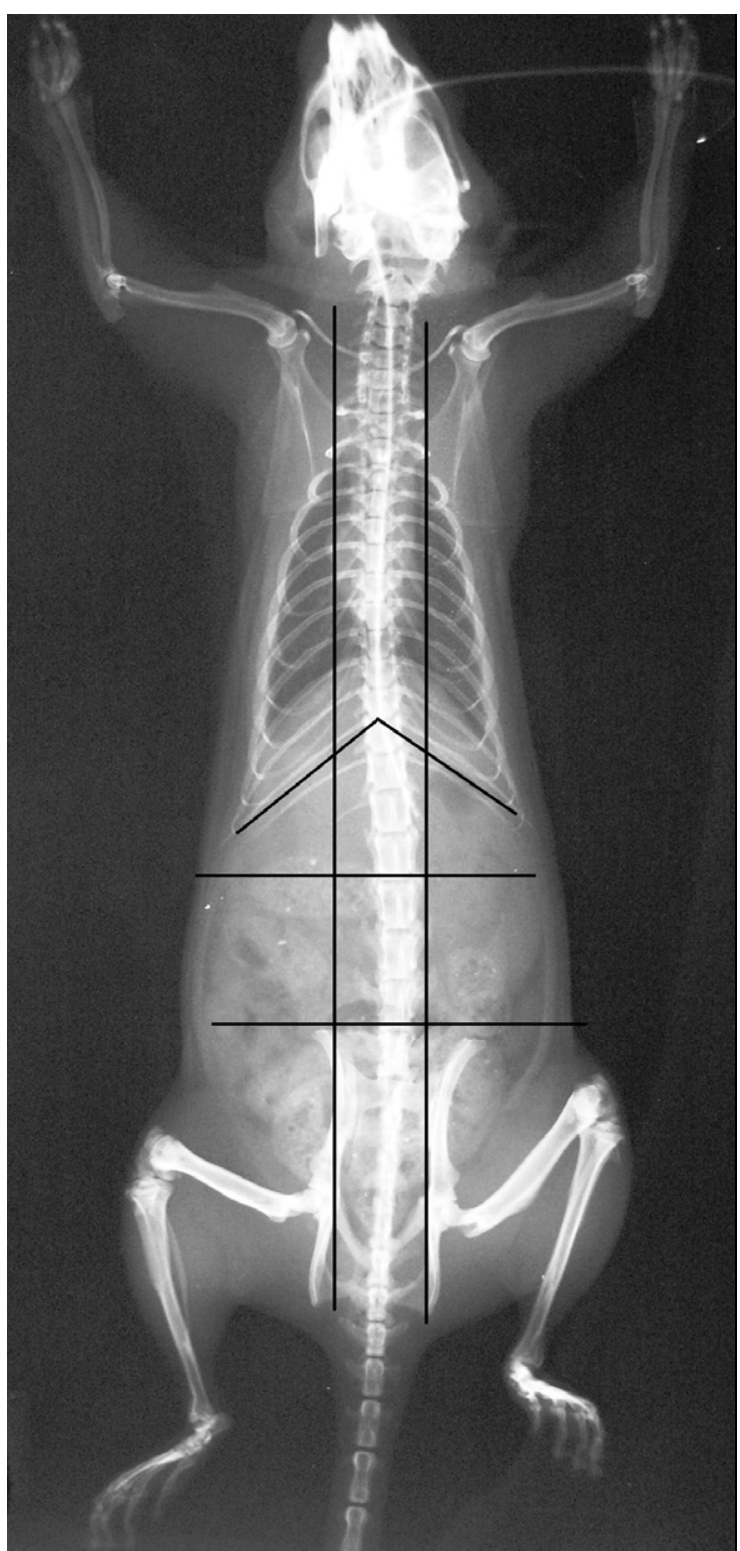

FIGURE 3 - Superimposition of the abdominal quadrants in the anteroposterior incidence

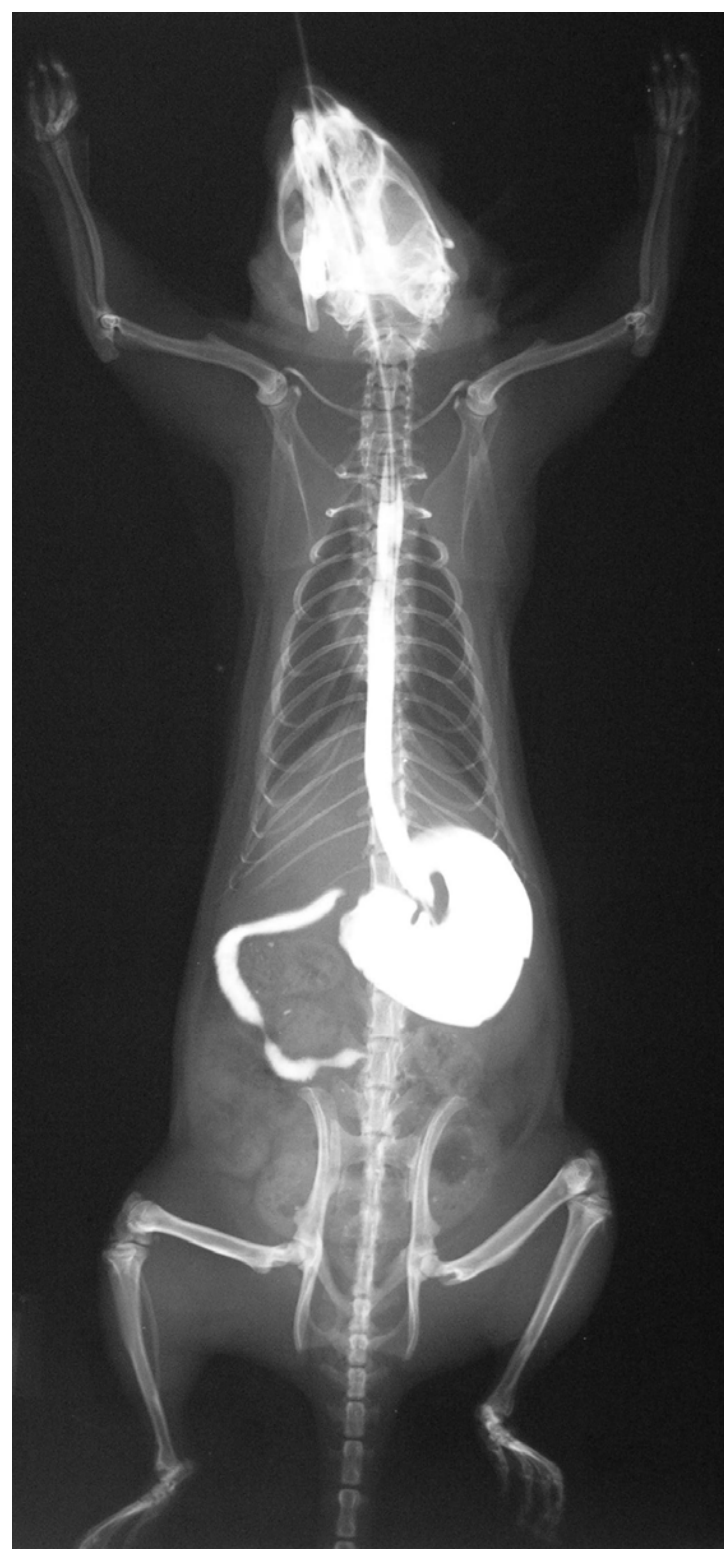

FIGURE 4 - Presence of contrast in the esophagus, stomach and duodenum in the anteroposterior incidence

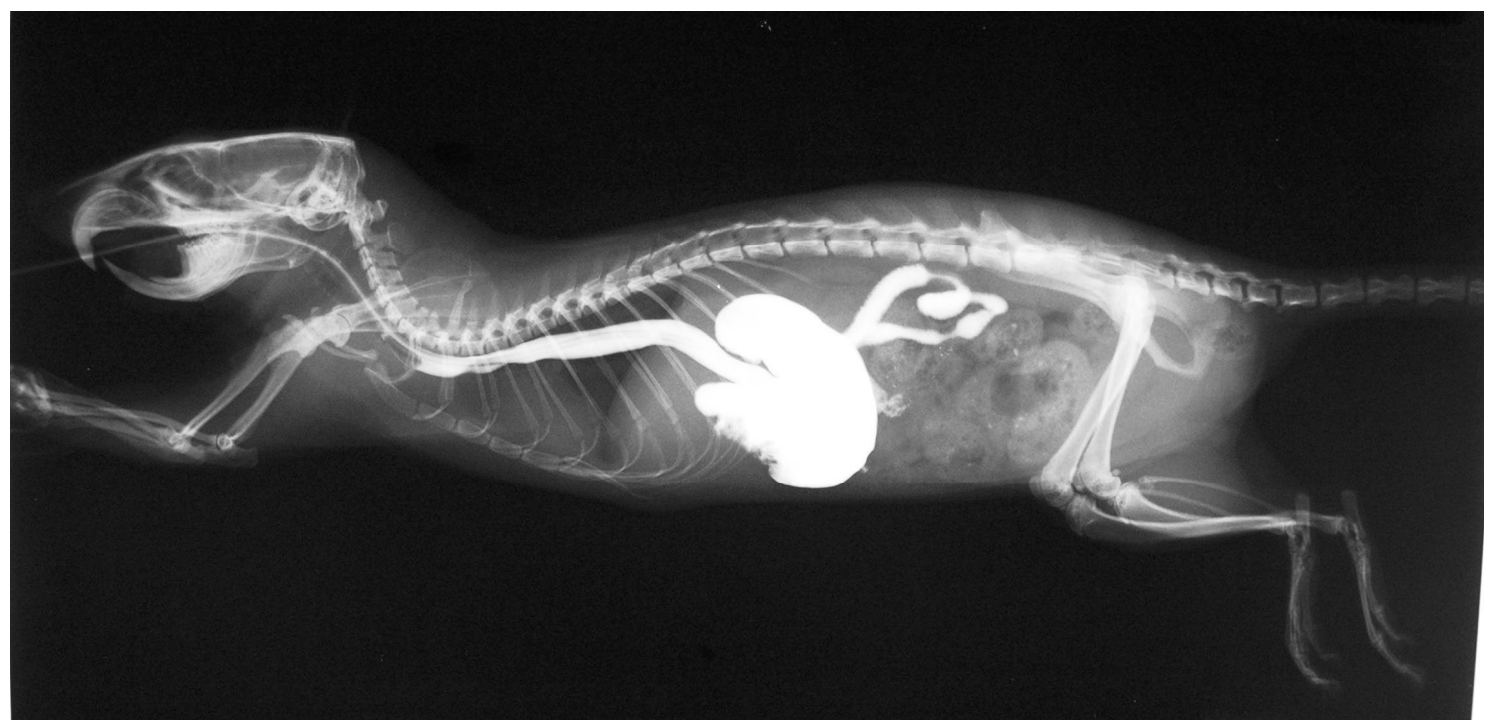

FIGURE 5 - Visualization of the lateral contrast radiography of the esophagus, stomach and duodenum 
The necropsy was carried out by median mento-pubic incision (Figure 6) and search for an anatomic changes, and did not reveal any structure that had not been detected by contrast radiography of the upper gastrointestinal series. In like manner, neither findings nor anatomical changes that led to the exclusion of one specimen were observed.

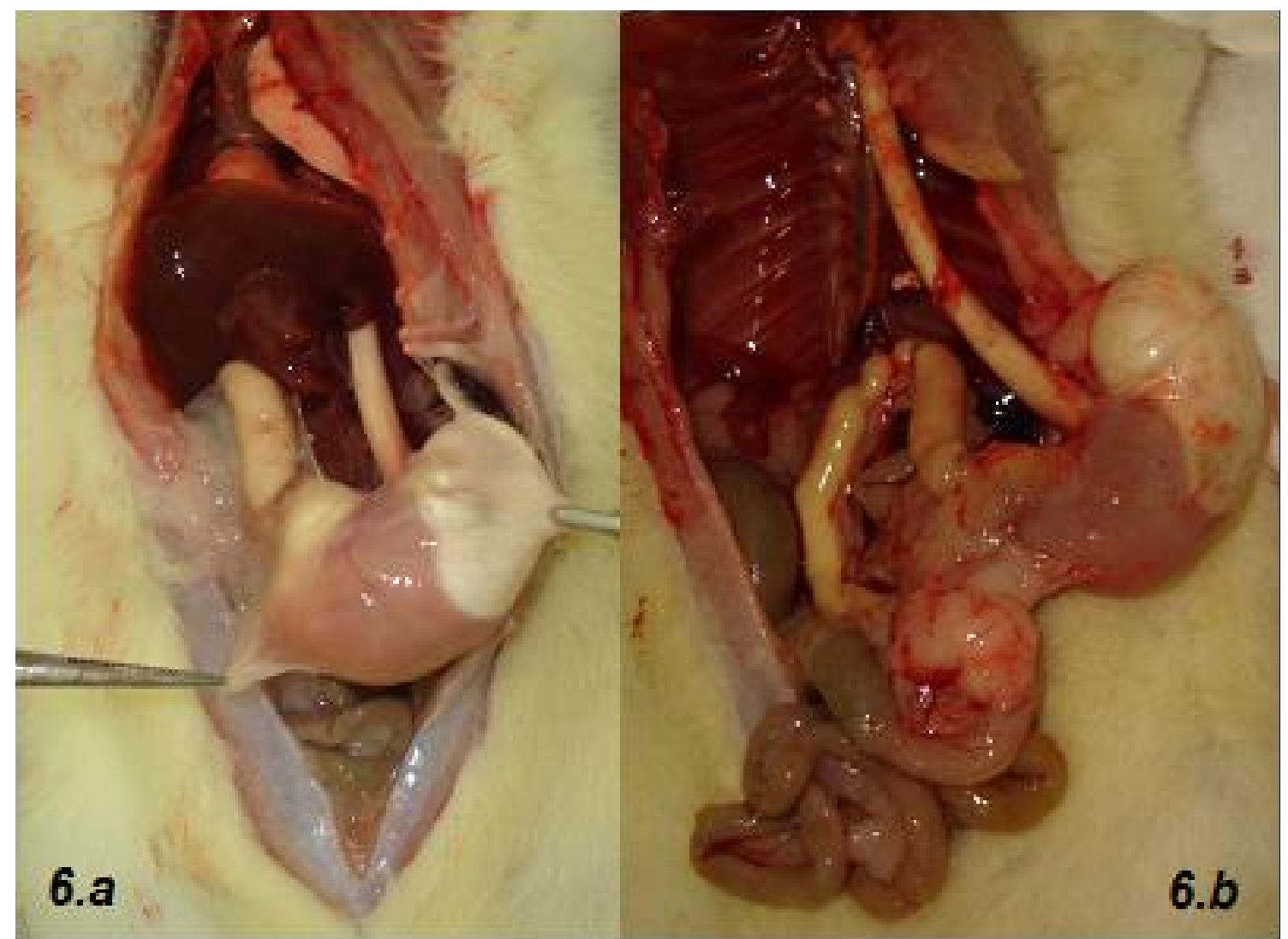

FIGURE 6 - a. Necropsy showing the median incision and the location of the organs in the abdominal cavity. b. Necropsy showing the thoracic and abdominal locations of the esophagus, as well as the stomach and the duodenum

During the second and third radiological examination, two cases of barium aspiration were observed. This event was visualized in the airways, trachea, main bronchia and bronchial tree.

To visualize the duodenum, an extra injection of contrast was required for two animals.

\section{Discussion}

The aim of contras radiology is the generation of radiological findings that may demonstrate changes as stenosis, fistulas, pervisouness of anasotmoses, and diverticula ${ }^{14}$. Some authors report the deformities of the esophagus after contrast investigation in Barret's esophagus, which may assist in the screening of patients with gastro-esophageal reflux symptoms $\mathrm{s}^{5,7,8,13}$. In the present study, no such changes were observed, which reveals the normal conditions of the specimens studied.

In the post-operative procedures of stomach and esophagus surgeries, it is possible to search for secondary deformities that appear after the surgical procedures, exactly when the trauma will not be surgical the esophagography may have sensitivity varying of $50-90 \%$ of the times ${ }^{13-16}$.

In the esophageal perforation, the diagnosis by contrast examination reveals the occurrence of contrast runoffs in $90 \%$ of the cases investigated ${ }^{9,10}$

The contrast radiology of the upper gastrointestinal series did not show contrast runoff occurrences, in any of the specimens investigated, or any type of lesion that was visible even after the conduction of subsequent necropsy ${ }^{14}$.

It was possible to clearly and safely determine all the anatomical aspects of the organs studied (location, anatomical relationships, morphological characteristics), which were confirmed by subsequent laparotomy. This finding revealed that the technique as proposed in the present study was an appropriate radiological approach to investigate the normal morphology of the esophagus, stomach and duodenum in Wistar female rats.

In two of the eight exams conducted, the contrast was visualized in the airways, due to the speed it was injected via gastrointestinal probe, impaired by the clearance of the esophagus. What the $100 \%$ were already foreseen with the barium sulfate use ${ }^{16}$.

This occurred at the first times the contrast was injected, and was not observed again afterwards.

Among the findings that justified the exclusion of the animals from controlled studies, it is important to consider the possibility of the occurrence any other abnormality that compromises the conduction of anterior evaluations in these animals. 


\section{Conclusion}

The radiological investigation was satisfactory and afforded to identify all the evaluated structures. Contrast radiology is useful and may be employed to assess the anatomy of the animal being studied.The experimental model described afforded to fully identify all organs investigated, as well as other occasional relevant findings. No anatomical anomalies in the subsequent necropsy, confirming the radiographic findings.

\section{References}

1. Dibble C, Levine MS, Rubesin SE, Laufer I, Katzka DA. Detection of reflux esophagitis on double-contrast esophagrams and endoscopy using the histologic findings as the gold standard. Abdom Imaging. 2004;29:421-5. 2. Styles RA, Gibb SP, Tarshis A, Silverman ML, Scholz FJ. Esophagogastric polyps: radiographic and endoscopic findings. Radiology. 1985;154:307-11.

3. Gupta S, Levine MS, Rubesin SE, Katzka DA, Laufer I. Usefulness of barium studies for differentiating benign and malignant strictures of the esophagus. AJR Am J Roentgenol. 2003;180:737-44.

4. Levine MS, Goldstein HM. Fixed transverse folds in the esophagus: a sign of reflux esophagitis. AJR Am J Roentgenol. 1984;43:275-8.

5. Seth NG. Barium studies in patients with barrett's esophagus: importance of focal areas of esophageal deformity. AJR Am J Roentgenol. 1994;163:65-7.

6. Ponsaing LG, Kiss K, Loft A, Jensen LI, Hansen MB. Diagnostic procedures for submucosal tumors in the gastrointestinal tract. World $\mathrm{J}$ Gastroenterol. 2007;13(24):3301-10.

7. Katada N, Hinder RA, Smyrk TC, Hiki Y, Kakita A. Duodenoesophageal reflux induces apoptosis in rat esophageal epithelium. Dig Dis Sci. 1999;44(2):301-10.
8. Melo LL, Kruel CD, Kliemann LM, Cavazzola LT, Boeno Rda L, Silber PC, Grossi RS. Influence of surgically induced gastric and gastroduodenal content reflux on esophageal carcinogenesis-experimental model in Wistar female rats. Dis Esophagus. 1999;12(2):106-15.

9. Pera M, Brito MJ, Poulsom R, Riera E, Grande L, Hanby A, Wright NA Duodenal-content reflux esophagitis induces the development of glandular metaplasia and adenosquamous carcinoma in rats. Carcinogenesis. 2000;21(8):1587-91.

10. Miwa K, Miyashita T, Hattori T. Reflux of duodenal or gastroduodenal contents induce esophageal carcinoma in rats. Nippon Rinsho. 2004;62(8):1433-8.

11. Zhang F, Altorki NK, Wu YC, Soslow RA, Subbaramaiah K, Dannenberg AJ Duodenal reflux induces cyclooxygenase-2 in the esophageal mucosa of rats: evidence for involvement of bile acids. Gastroenterology. 2001;121(6):1391-9.

12. Clark GW, Smyrk TC, Mirvish SS, Anselmino M, Yamashita Y, Hinder RA, DeMeester TR, Birt DF. Effect of gastroduodenal juice and dietary fat on the development of Barrett's esophagus and esophageal neoplasia: an experimental rat model. Ann Surg Oncol. 1994;1(3):252-61.

13. César JMS, Petroianu A, Gouvêa AP, Alvin DR. Reopening of the gastroduodenal pylorus after its closure in rats. J Surg Res. 2008;144:89-93. 14. Weigelt JA, Thal ER, Snyder WH 3rd, Fry RE, Meier DE, Kilman WJ. Diagnosis of penetrating cervical esophageal injuries. Am J Surg. 1987; 154:619-22.

15. Ginai AZ, ten Kate FJ, ten Berg GM, Hoornstra K. Experimental evaluation of various available contrast agents for use in the upper gastrointestinal tract in case of suspected leakage: effects on mediastinum. Br J Radiol. 1985;58(691):585-92.

16. Vaezi MF, Baker ME, Achkar E, Richter JE. Timed barium oesophagram: better predictor of long term success after pneumatic dilation in achalasia than symptom assessment. Gut. 2002;50(6):765-70.

\title{
Correspondence:
}

João Vicente Machado Grossi

Rua Carlos Trein Filho, 1271/401

96450-120 Porto Alegre - RS Brazil

Phone: (55 51)9958-3750

jvicentegrossi@gmail.com

Conflict of interest: none Financial source: none

jicentegrossi@gmail.com

Received: April 09, 2009

Review: June 13, 2009

Accepted: July 28, 2009

\author{
How to cite this article \\ Grossi JVM, Nicola RF, Bigolin AV, Montes JHM, Lima JNC, Kraemer R, Cavazzola LT. Description of the technique of upper \\ gastrointestinal series radiological examination for the evaluation of the esophagus, stomach and duodenum of Wistar female rats. Acta \\ Cir Bras. [serial on the Internet] 2009 Nov-Dec;24(6). Available from URL: http://www.scielo.br/acb
}

